\title{
Consumer Motivation to Enhance Purchase Intention Towards Electric Vehicles in Malaysia
}

\author{
Haider Ali Abbasi ${ }^{1,}$, Zullina Hussain Shaari ${ }^{1}$ Wajiha Moughal ${ }^{1}$ \\ ${ }^{1}$ Management and Humanities Department Universiti Teknologi PETRONAS
}

\begin{abstract}
Transportation is extremely important in contributing to the life quality development of urban areas. However, it has influenced negatively on individuals and the environment due to carbon emissions and gases. Worldwide, organizations and countries are exploring a solution and have developed Electric Vehicles (EVs) as the best possible solution. Electric vehicles emit no exhaust emissions and are powered by batteries. The adoption rate of EVs in rich countries is increasing year after year, while consumer adoption intention of EVs in poor countries is quite low, particularly in Malaysia. The ownership percentage of Internal Combustion Engine Vehicles (ICEs) in Malaysia is 93 percent, placing it near the top of the globe, but EV adoption is just about 3.5 percent. Consumer awareness of EVs is quite low, which is why consumer adoption intentions toward EVs are not increasing. Malaysia is the world's 26th highest emitter of carbon and greenhouse gases (GHG). This study will assist in identifying the characteristics that can maximize consumer interest in EVs and will be beneficial to the government and industry in developing the market as stated in the Paris accord and achieving the Carbon Neutral Nation 2050 aim. The study will go through the motivators that lead consumers to purchase EVs. These characteristics will provide transportation sectors insights on bridging the demand and supply of sustainable vehicles.
\end{abstract}

\section{Introduction}

Sustainable Development Goals (SDGs) in United Nations 2030 agenda has gained significant attention among academics and policy-makers to deliver numerous benefits for the health, environment, and economy, especially in urban areas where more than two-thirds of the population will live by 2050 (DESA, 2018). In September 2019, UN Secretary-General Ban Ki-moon urged all sectors of society to step up efforts to address global issues like climate change, poverty, and inequality (UN, 2020). Overpopulation, climate change, inadequate infrastructure and resources, harsh weather, linked sickness, air pollution, and loss of productivity are problems experienced by many countries across the world (J. Salmond, Sabel, \& Vardoulakis, 2018; J. A. Salmond et al., 2016; Vardoulakis \& Kinney, 2019), where Greenhouse Gases (GHG) are significant source of climate change (Farooqi et al., 2020). Promoting the SDGs as a means of addressing environmental health threats, such as climate change (Goal 13), which should be enhanced to promote wellbeing and good

\footnotetext{
*Corresponding author : haider_17007471@utp.edu.my
} 
health. The development of nations worldwide is contingent upon their transportation infrastructure (Adler, 1987). Transportation, whether in urban or rural, makes a significant contribution to the enhancement of one's quality of life (Moore, 2013). GHG released from the fossil fuels comprises mainly on carbon dioxide ( $\mathrm{Co} 2)$ and methane, which are significant contributor towards global warming (Farooqi et al., 2021). Numerous countries worldwide have faced these combined challenges: population growth, climate change, insufficient infrastructure and resources, harsh weather, associated sickness, air pollution, and loss of productivity (J. Salmond et al., 2018; J. A. Salmond et al., 2016; Vardoulakis \& Kinney, 2019). Promoting the SDGs for tackling environmental health threats, such as climate change (Goal 13) and carbon emissions reduction, which should be prioritized for human well-being and health (Goal 3), instantly (Howden-Chapman, Keall, Whitwell, \& Chapman, 2020). Well-planned sustainable modes of transport, renewable energy, land use, and waste management all have the potential to improve the environment's, as well as human and animal, quality of life and health (Vardoulakis \& Kinney, 2019).

Efficient transportation infrastructure is necessary for communities to thrive and residents to have a stable source of income, and a well-organized transportation system contributes significantly to environmental and economic growth (Browne \& Ryan, 2011). The transportation sector undoubtedly has a negative impact on the environment as a result of many gas emissions such as $\mathrm{CO} 2, \mathrm{NOx}$, and others. The energy consumed by the transportation sector results in a complete reliance on petroleum (Turcksin et al., 2011). Because the use of Internal Combustion Engine (ICE) vehicles results in the emission of a variety of gases, governments worldwide are more concerned with preventing the use of ICE vehicles through the implementation of severe rules (Santos, Behrendt, \& Teytelboym, 2010). Globally, governments are more concerned with transitioning to sustainable modes of transport (Qureshi \& Lu, 2007). António Guterres, Secretary-General of the United Nations, calls on all countries to adhere to strict laws and measures for achieving net-zero carbon emissions by 2050 (UNFCCC, 2019). This is feasible through the adoption of sustainable transport, which is defined as innovation in the transportation industry that results in sustainable progress and minimal carbon emissions. Electric Vehicles (EVs), which include Hybrid Electric Vehicles (HEVs), Plug-in Hybrid Electric Vehicles (PHEVs), Battery Electric Vehicles (BEVs), and Fuel Cell Vehicles (FCVs), are the primary mode of sustainable transportation.

Malaysia is the world's 25th highest emitter of greenhouse gases (GHGs), and the transport industry is the country's second-largest source of carbon emissions (Star, 2019). Globally, Malaysia has the third leading combustion engine vehicle ownership ratio with 93\% (Malaysiakini, 2014), and the transport sector uses about 35\% of the country's total production output. Consistent urbanization, economic development, and rising income have resulted in a rapid increase in car ownership; yet, air pollution and environmental risks associated with GHG emissions remain the primary source of worry (Shariff, 2012). Malaysia has also committed to reducing GHG emissions by 2030 in its Greentech Master Plan (KeTTHA, 2017), and transportation is Malaysia's second-largest source of carbon emissions. Simply introducing sustainable automobiles is insufficient until they gain consumer acceptance and support. Acceptability of novel technologies requires financial and educational support, as well as consumer acceptance, especially emerging countries such as Malaysia (Karp, 2016). If consumers lack the desire to acquire EVs, production alone will not suffice. Despite their environmental benefits, electric vehicles have very little market share. While there are still considerable obstacles to the easy uptake of EVs in Malaysia, the purchase of EVs can be boosted by prospective consumer supply and demand-side support. Effective retail tactics should be implemented by EV automakers in order to increase EV adoption. Financing the manufacture of EVs needs a large capital investment, which can 
affect the final price. Governments should encourage local professionals to develop technologies that can be subsidized to make the product more accessible (Star, 2019). Price can be further reduced by the economies of scale if demand has been settled. And, consumer awareness and motivation about EVs can further effective in creating demand. Without knowing the consumer demands, the EVs market will have unclear demand. EVs supply in the Malaysian market is already available, however, demand or sale of EVs is not effective. So, this research initiated to identify the factors which can enhance consumer behavior towards EVs sale. Maximum adoption of EVs can be helpful for the Malaysian government to have carbon free environment and attain SDGs of climate change.

\section{Literature Review}

Generally, innovative technology developers confront obstacles in their efforts to attract users and grow the product's future market share (J. J. Mohr, Sengupta, \& Slater, 2010). Researchers have used a variety of motivation models, including the consumer choice model (Bandivadekar, 2008; Hao, Ou, Du, Wang, \& Ouyang, 2014; Helveston et al., 2015; Zhang, $\mathrm{Yu}, \&$ Zou, 2011), a cohort estimation model for vehicle survival (Higuchi, Wada, Nakakubo, \& Tokai, 2012), and an agent-based model (Struben \& Sterman, 2008). According to Sang and Bekhet (2015), customer purchase behavior is more influenced by social, environmental, financial, performance, demographic, infrastructure readiness, and government intervention. In Malaysia, real EV purchases are extremely low compared to consumer stated preferences (Coffman, Bernstein, \& Wee, 2017). Li, Du, and Wei (2014) used the Probit model to label the factors that influence the purchase intentions of electric and flexible fuel vehicles. Human behavior has been investigated in a variety of ways by many researchers. For example, Ajzen (1991) proposed the (TBP) theory of planned behavior, which enables individuals to choose their conduct based on comprehensible evaluations. Diffusion of forecasting models for the electric vehicle market proposed by various researchers (B. M. Al-Alawi \& T. H. Bradley, 2013; Becker, Sidhu, \& Tenderich, 2009). Sheth, Newman, and Gross (1991) demonstrate in their study that perceived value (PV) functionalities are not restricted to price and quality considerations. PV also refers to an overall assessment of the products' customer performance (Bolton \& Drew, 1991; Patterson \& Spreng, 1997). PV appears to be an effective predictor of consumer behavior, enabling businesses to increase the value of their products (Geyskens, Steenkamp, \& Kumar, 2006). Numerous elements affecting customer behaviour toward items are described in detail below.

\subsection{Motivational Factors}

Numerous factors that can improve customer behavior have been discussed. Effort expectancy, performance expectancy, government incentives, societal influence, environmental concern, perceived enjoyment, new technology, and fuel efficiency are all similar constructs that have been utilised in the literature. The purpose of this study is to discuss encouraging aspects that appear to be significant in enhancing customer behavior. T.L. Childers ( 2001) discovered the intrinsic motivational variables (customization, advancement, and perceived enjoyment) that can boost customer behavioral intention in his study. However, the other constructs described above have not been used in the context of motivating factors. This study will examine the elements that influence consumer motivation to acquire electric vehicles.

Four motivational variables to increase consumer adoption intention have been identified as a motivator in the pursuit of EVs based on an exploratory study. 


\subsubsection{Fuel Efficiency}

Consumer acceptance of EVs is heavily influenced by their purchase price (Lane \& Potter, 2007). Electric vehicles are regarded as more fuel-efficient and have a cheaper long-term fuel cost than conventional combustion engine vehicles (Lane \& Potter, 2007). Lower gasoline costs can be an effective strategy for customer incentive, as humans are wired to seek efficiency and cost savings. The fuel economy benefit can be used to attract and persuade consumers to purchase EVs (Ozaki \& Sevastyanova, 2011). The fuel economy and low maintenance costs of EVs can be used to influence customer behaviour; through advertising and awareness, consumer motivation to purchase sustainable vehicles can be increased. Numerous studies have demonstrated that ICE users can save money on higher fuel and gasoline costs in the long term by adopting these low-cost EVs (B. Al-Alawi \& T. Bradley, 2013; Prud'homme \& Koning, 2012; Tseng, Wu, \& Liu, 2013; Wu, Dong, \& Lin, 2014).

H1: Fuel Efficiency will positively affect consumer's adoption intention towards EVs.

\subsubsection{Technophilia}

Technophilia is a term that refers to a consumer's enthusiasm for, openness toward, and curiosity with technology. According to Rogers (2003), consumers are eager to adopt technophiles during the early stages of product development when the product is not widely available on the market. Hirschman (1980) viewed new technology goods as an attempt to discover something novel and novel. Being technologically savvy and suspicious about novel products increases consumer propensity to purchase (Egbue \& Long, 2012; Oliver \& Rosen, 2010). While driving electric vehicles, consumers share their experiences with new technology with others (Axsen \& Kurani, 2012). New products affect a consumer on the lookout for breakthrough technology (Biswas \& Roy, 2015; Im, Bayus, \& Mason, 2003). The product's efficacy is a critical component in determining whether or not novel technology will be accepted (Venkatesh, Morris, Davis, \& Davis, 2003).

H2: Technophilia will positively affect consumer's adoption intention towards EVs

\subsubsection{Perceived Enjoyment}

According to experts, perceived happiness may be divided into two categories: helping others and socializing with friends. Hsu and Lin (2008), described enjoyment as "enjoyment and fun" when users of the internet participate in social networking sites. They also indicated that enjoyment is a component that influences users' intention to participate. Venkatesh (2000) quantified technology through the lens of perceived enjoyment, which he defined as "the degree to which a certain system action is seen to be delightful, independent of any repercussions of performance by using the system." According to Liao, Tsou, and Shu (2008); (Venkatesh, Thong, \& Xu, 2012), perceived enjoyment has been regarded as the most effective motivator, as it affects human attitude and intention toward a certain thing. Perceived enjoyment and ease of use have been found to be more predictive of attitude toward the purchase than perceived utility (Liao et al., 2008). being an innovative technology, have a faster acceleration and a smoother ride than conventional vehicles, which may benefit consumers' adoption of EVs (Miao, Xu, Zhang, \& Jiang, 2014). 
H3: Perceived enjoyment will positively affect consumer's adoption intention towards EVs.

\subsubsection{Environmental concerns (EC)}

Consumers' sustainable environmental concerns influence their purchasing decisions about environmentally friendly products (Balderjahn, 1988; Ellen, Wiener, \& Cobb-Walgren, 1991; Martin, Shaheen, Lipman, \& Lidicker, 2009; Roberts \& Bacon, 1997). The delicate issue of energy conservation in light of climate change, as well as increased awareness of clean and safe energy, are obvious facets of being environmentally conscious (Zimmer, Stafford, \& Stafford, 1994). Recent research have demonstrated that innovative and sustainable automotive technology can help consumers make more environmentally conscious choices (Ewing \& Sarigöllü, 1998; Gould \& Golob, 1998; Schuitema, 2013). Environmental concern is a major predictor of evolving consumer attitudes toward EVs and has a considerable positive effect on EV purchase intentions (Sabrina Habich Sobiegallaa, December 2018). Yadav and Pathak (2016) assert that environmental concern has emerged as a critical predictor of behavior toward green items.

H4: Environmental concern will positively affect consumer's adoption intention towards EVs.

\subsubsection{Perceived Environmental Knowledge (PEK)}

PEK is defined as persons who possess knowledge of the environment, the earth's ecology, and the effects of human actions on the environment (Arcury \& Johnson, 1987). Hines, Hungerford, and Tomera (1987) described environmental knowledge as having two domains: concrete and abstract. While abstract knowledge refers to possessing information and knowledge about environmental problems and their solutions, concrete knowledge refers to knowledge about behavior that has a tangible impact on the environment. Consumer research has a considerable impact on decision making; the information gathered and organized by an individual is contingent on the perceived knowledge he holds (Alba \& Hutchinson, 1987). The consumer's perception of a product is determined by the information and knowledge about it (Murray \& Schlacter, 1990), as is the sort of information employed in the product decision-making process (Brucks, 1985). Environmental awareness can be a powerful motivator of consumer behavior (Boo \& Park, 2013). According to Chan, Hon, Chan, and Okumus (2014), employees who have a favorable perception of environmental knowledge, awareness, and concern influence consumer behavior. L. A. Mohr, Eroğlu, and Ellen (1998) used the widely used measure of Perceived environmental knowledge.

H5: Perceived Environmental Knowledge will positively affect consumer's adoption intention towards EVs

\subsection{Diffusion of Advertisement}

Advertising enables a business to make its products known to the public, which is made feasible through the use of social media (Berger, 2015). Misperceptions and a lack of information about EVs must obscure the consumer concept of revolutionary technology (O'Neill, Moore, Kelleher, \& Brereton, 2019). Given the low level of customer awareness and knowledge of EVs, social media can be extremely beneficial in influencing consumer purchasing behavior. In today's environment, customers are more concerned with the use of various social media platforms such as WhatsApp, Facebook, YouTube, Twitter, and 
Google+ (Alalwan, Rana, Dwivedi, \& Algharabat, 2017; Kapoor et al., 2018; Kim \& Kim, 2018; Shareef, Mukerji, Dwivedi, Rana, \& Islam, 2019). The social media platforms mentioned above enable humans and organizations to create a new educational, social, commercial, and political space for information sharing and interaction around items (Hawkins \& Vel, 2013; Rathore, Ilavarasan, \& Dwivedi, 2016; Usher et al., 2014; Zeng \& Gerritsen, 2014; Zhu \& Chen, 2015). The dissemination of advertisements regarding EVs on these platforms has the potential to increase customer awareness and persuade people to acquire these vehicles. Social media has the potential to alter human behavior and nature in relation to products, society, and organizations. Social media boosts marketing efforts and serves as an active platform for advertisement on a global scale. Advertisements can help increase the consumer's awareness of a certain product. The degree of EV adoption is quite low, and the primary reason is that most consumers are unfamiliar of EVs and their characteristics. Advertisement can be credited with influencing consumer preferences and values in favor of products.

H6: Diffusion of advertisement will positively moderate the relationship between fuel efficiency and adoption intention towards EVs.

H7: Diffusion of advertisement will positively moderate the relationship between technophilia and adoption intention towards EVs.

H8: Diffusion of advertisement will positively moderate the relationship between perceived enjoyment and adoption intention towards EVs.

H9: Diffusion of advertisement will positively moderate the relationship between environmental concern and adoption intention towards EVs.

H10: Diffusion of advertisement will positively moderate the relationship between perceived environmental knowledge and adoption intention towards EVs

\subsection{Diffusion of Innovation (DOI)}

DOI is the most relevant theory for examining the intention of technology users to adopt new technologies in enlightening situations (Medun, 2001). Diffusion research requires innovation in technology, which is why Rogers (2003) used the terms innovation and technology interchangeably. According to Rogers (2003), adoption is defined as "the optimal method for utilizing the invention as a readily available resource," and rejection is defined as "the decision not to adopt an innovation." The diffusion process is described as "the process by which innovations are communicated among society members via certain communication channels at a specific period" (Rogers, 2003). This definition's primary components are innovation, communication routes, society or social members, and time.

According to Rogers (2003) these components are "diffusion as a process of communication about an innovation among social members through communication channels in a certain period."

"Communication as a process in which members of society create and share information with others in order to achieve mutual understanding"

"Process of Innovation dissemination, categorization, communication, and acceptance rating required time dimension" and "Social System as a set of connected units engaged in specific issue solving to reach a shared purpose."

Diffusion of Innovation in Motivation can occur when new technological vehicles are discussed among society members via certain communication channels. Consumer motivation for specific products can be increased via DOI. This hypothesis is important in characterizing the diffusion of innovative vehicles among members of society. 


\subsection{Theoretical Model}

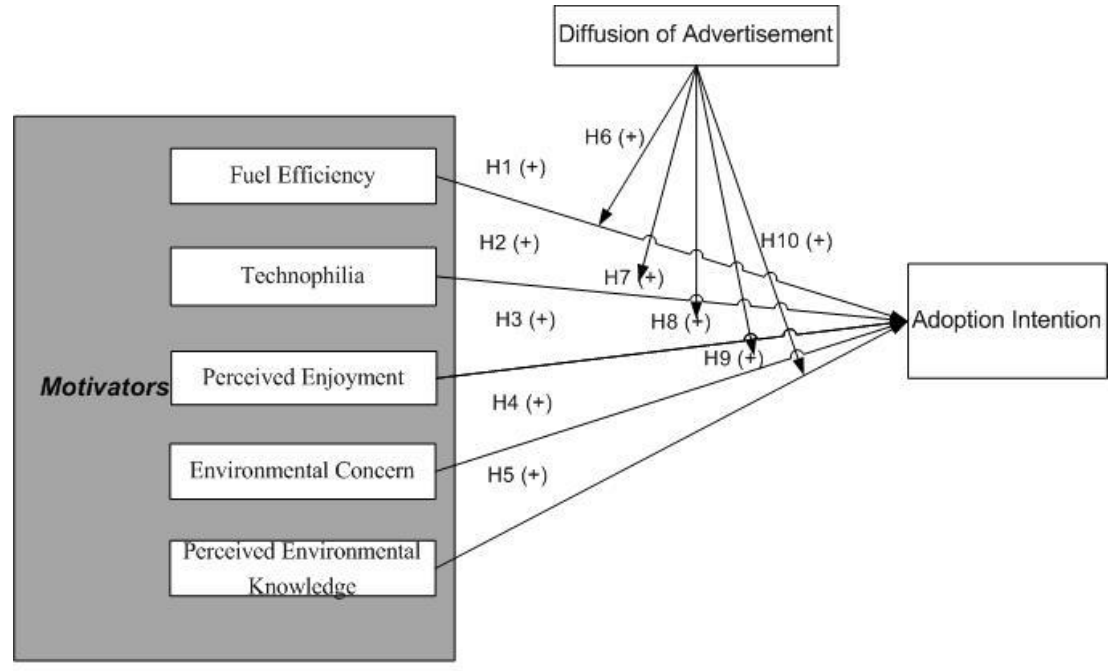

Fig 1: Theoretical model

\section{Theoretical Framework of the Study}

The structure depicted in Figure 1 describes the independent and dependent variables, as well as their connection, based on the literature review described. This framework has two features to explore, first the relationship between fuel efficiency, technophilia, perceived enjoyment, environmental concern, and perceived environmental knowledge towards adoption intention. And the second moderating effect of diffusion of advertisement to influence consumer adoption intention towards EVs.

\section{Conclusion}

The worldwide government acceptance of EVs is helpful to reduce transport carbon emission and to attain the sustainable development Goal of Climate Change, however, the demand for EVs among consumers is very low. The motivating factors suggested in this study will be effective to enhance consumer adoption behavior towards EVs. The advertisement diffusion will be helpful to enhance consumer awareness and encourage them to buy these sustainable innovative EVs. With the help of advertisement, the motivation level of the consumer will be encouraged to develop purchase behavior towards EVs. Motivational factors with the help of advertisement can enhance consumer adoption intention of EVs, as these are sustainable and environmentally friendly which will help to reduce the transport GHG emission. Sustainability depends on the three pillars that are: environment, society, and economic development. This study suggested the solution to enhance consumer motivation towards different prospects of EVs. This study suggested the concept of enhancing consumer motivation. Future research could be possible on the implementation of these studies into actual data. The causal relationship in the paper is still unknown so structural equation modeling can be applied to further studies analysis. This paper roughly analyzes the different variables, the deeper relationship among these could be applied to other innovative technologies. 


\section{Acknowledgment}

The author would like to thank PETRONAS for allowing the author to utilize the data and for providing support throughout the research.

\section{References}

Adler, H. A. (1987). Economic appraisal of transportation projects: A manual with case studies. Economic Development Institute of the World Bank.

Ajzen, I. (1991). The theory of planned behavior. Organizational behavior and human decision processes, 50(2), 179-211.

Al-Alawi, B., \& Bradley, T. (2013). Applied Energy, 103(null), 488.

Al-Alawi, B. M., \& Bradley, T. H. (2013). Review of hybrid, plug-in hybrid, and electric vehicle market modeling studies. Renewable and Sustainable Energy Reviews, 21, 190-203.

Alalwan, A. A., Rana, N. P., Dwivedi, Y. K., \& Algharabat, R. (2017). Social media in marketing: A review and analysis of the existing literature. Telematics and Informatics, 34(7), 1177-1190.

Alba, J. W., \& Hutchinson, J. W. (1987). Dimensions of consumer expertise. Journal of consumer research, 13(4), 411-454.

Arcury, T. A., \& Johnson, T. P. (1987). Public environmental knowledge: A statewide survey. The Journal of Environmental Education, 18(4), 31-37.

Axsen, J., \& Kurani, K. S. (2012). Interpersonal influence within car buyers' social networks: applying five perspectives to plug-in hybrid vehicle drivers. Environment and planning A, 44(5), 1047-1065.

Balderjahn, I. (1988). Personality variables and environmental attitudes as predictors of ecologically responsible consumption patterns. Journal of business research, 17(1), 51-56.

Bandivadekar, A. P. (2008). Evaluating the impact of advanced vehicle and fuel technologies in US light duty vehicle fleet. Massachusetts Institute of Technology, Engineering Systems Division ...,

Becker, T. A., Sidhu, I., \& Tenderich, B. (2009). Electric vehicles in the United States: a new model with forecasts to 2030. Center for Entrepreneurship and Technology, University of California, Berkeley, 24.

Berger, A. A. (2015). Ads, fads, and consumer culture: Advertising's impact on American character and society: Rowman \& Littlefield.

Biswas, A., \& Roy, M. (2015). Leveraging factors for sustained green consumption behavior based on consumption value perceptions: testing the structural model. Journal of Cleaner Production, 95, 332340 . 
Bolton, R. N., \& Drew, J. H. (1991). A multistage model of customers' assessments of service quality and value. Journal of consumer research, 17(4), 375-384.

Boo, S., \& Park, E. (2013). An examination of green intention: The effect of environmental knowledge and educational experiences on meeting planners' implementation of green meeting practices. Journal of Sustainable Tourism, 21(8), 1129-1147.

Browne, D., \& Ryan, L. (2011). Comparative analysis of evaluation techniques for transport policies. Environmental Impact Assessment Review, 31(3), 226-233.

Brucks, M. (1985). The effects of product class knowledge on information search behavior. Journal of consumer research, 12(1), 1-16.

Chan, E. S., Hon, A. H., Chan, W., \& Okumus, F. (2014). What drives employees' intentions to implement green practices in hotels? The role of knowledge, awareness, concern and ecological behaviour. International Journal of Hospitality Management, 40, 20-28.

Coffman, M., Bernstein, P., \& Wee, S. (2017). Electric vehicles revisited: a review of factors that affect adoption. Transport Reviews, 37(1), 7993.

DESA, U. (2018). $68 \%$ of the world population projected to live in urban areas by 2050, says UN. United Nafions Department of Economic and Social Affairs.

Egbue, O., \& Long, S. (2012). Barriers to widespread adoption of electric vehicles: An analysis of consumer attitudes and perceptions. Energy Policy, 48, 717-729.

Ellen, P. S., Wiener, J. L., \& Cobb-Walgren, C. (1991). The role of perceived consumer effectiveness in motivating environmentally conscious behaviors. Journal of public policy \& marketing, 10(2), 102-117.

Ewing, G. O., \& Sarigöllü, E. (1998). Car fuel-type choice under travel demand management and economic incentives. Transportation research part D: transport and environment, 3(6), 429-444.

Farooqi, A. S., Al-Swai, B. M., Ruslan, F. H., Mohd Zabidi, N. A., Saidur, R., Syed Muhammad, S. A. F. a., \& Abdullah, B. (2020). Catalytic conversion of greenhouse gases $(\mathrm{CO} 2$ and $\mathrm{CH} 4)$ to syngas over $\mathrm{Ni}$ based catalyst: Effects of Ce-La promoters. Arabian Journal of Chemistry, 13(6), 5740-5749. doi:https://doi.org/10.1016/j.arabjc.2020.04.012

Farooqi, A. S., Yusuf, M., Mohd Zabidi, N. A., Saidur, R., Sanaullah, K., Farooqi, A. S., ... Abdullah, B. (2021). A comprehensive review on improving the production of rich-hydrogen via combined steam and $\mathrm{CO} 2$ reforming of methane over Ni-based catalysts. International 
Journal of Hydrogen Energy.

doi:https://doi.org/10.1016/j.ijhydene.2021.01.049

Geyskens, I., Steenkamp, J.-B. E., \& Kumar, N. (2006). Make, buy, or ally: A transaction cost theory meta-analysis. Academy of management journal, 49(3), 519-543.

Gould, J., \& Golob, T. F. (1998). Clean air forever? A longitudinal analysis of opinions about air pollution and electric vehicles. Transportation research part D: transport and environment, 3(3), 157-169.

Hao, H., Ou, X., Du, J., Wang, H., \& Ouyang, M. (2014). China's electric vehicle subsidy scheme: Rationale and impacts. Energy Policy, 73, 722-732.

Hawkins, K., \& Vel, P. (2013). Attitudinal loyalty, behavioural loyalty and social media: An introspection. The Marketing Review, 13(2), 125141.

Helveston, J. P., Liu, Y., Feit, E. M., Fuchs, E., Klampfl, E., \& Michalek, J. J. (2015). Will subsidies drive electric vehicle adoption? Measuring consumer preferences in the US and China. Transportation Research Part A: Policy and Practice, 73, 96-112.

Higuchi, Y., Wada, N., Nakakubo, T., \& Tokai, A. (2012). Scenario analysis on the impact of diffusion of next generation vehicles on material consumption and GHG emissions. In Design for Innovative Value Towards a Sustainable Society (pp. 599-604): Springer.

Hines, J. M., Hungerford, H. R., \& Tomera, A. N. (1987). Analysis and synthesis of research on responsible environmental behavior: A meta-analysis. The Journal of Environmental Education, 18(2), 1-8.

Hirschman, E. C. (1980). Innovativeness, novelty seeking, and consumer creativity. Journal of consumer research, 7(3), 283-295.

Howden-Chapman, P., Keall, M., Whitwell, K., \& Chapman, R. (2020). Evaluating natural experiments to measure the co-benefits of urban policy interventions to reduce carbon emissions in New Zealand. Science of the Total Environment, 700, 134408.

Hsu, C.-L., \& Lin, J. C.-C. (2008). Acceptance of blog usage: The roles of technology acceptance, social influence and knowledge sharing motivation. Information \& Management, 45(1), 65-74.

Im, S., Bayus, B. L., \& Mason, C. H. (2003). An empirical study of innate consumer innovativeness, personal characteristics, and new-product adoption behavior. Journal of the academy of marketing science, 31(1), 61-73.

Kapoor, K. K., Tamilmani, K., Rana, N. P., Patil, P., Dwivedi, Y. K., \& Nerur, S. (2018). Advances in social media research: Past, present and future. Information Systems Frontiers, 20(3), 531-558. 
Karp, J. (2016). Managing the Risks of Renewable Energy Projects in Developing Countries.

KeTTHA. (2017). Green Technology Master Plan Malaysia 2017-2030

(GTMP). Ministry of Energy, Green Technology and Water (KeTTHA), Putrajaya, Malaysia.

Kim, N., \& Kim, W. (2018). Do your social media lead you to make social deal purchases? Consumer-generated social referrals for sales via social commerce. International Journal of Information Management, 39, 38-48.

Lane, B., \& Potter, S. (2007). The adoption of cleaner vehicles in the UK: exploring the consumer attitude-action gap. Journal of Cleaner Production, 15(11-12), 1085-1092.

Li, A., Du, N., \& Wei, Q. (2014). The cross-country implications of alternative climate policies. Energy Policy, 72, 155-163.

Liao, C.-H., Tsou, C.-W., \& Shu, Y.-C. (2008). The roles of perceived enjoyment and price perception in determining acceptance of multimedia-on-demand. International Journal of Business and Information, 3(1), 27-52.

Malaysiakini. (2014). The Malaysian transport system. Retrieved from https://www.malaysiakini.com/letters/280148

Martin, E., Shaheen, S. A., Lipman, T. E., \& Lidicker, J. R. (2009). Behavioral response to hydrogen fuel cell vehicles and refueling: results of California drive clinics. International Journal of Hydrogen Energy, 34(20), 8670-8680.

Medun, B. D. (2001). The factors that may influence a faculty members' decision to adopt electronic technologies in instruction. Virginia Tech,

Miao, R., Xu, F., Zhang, K., \& Jiang, Z. (2014). Development of a multiscale model for customer perceived value of electric vehicles. International Journal of Production Research, 52(16), 4820-4834.

Mohr, J. J., Sengupta, S., \& Slater, S. F. (2010). Marketing of hightechnology products and innovations: Pearson Prentice Hall.

Mohr, L. A., Eroğlu, D., \& Ellen, P. S. (1998). The development and testing of a measure of skepticism toward environmental claims in marketers' communications. Journal of consumer affairs, 32(1), 3055.

Moore, T., \& Pulidindi, J. . (2013). Understanding urban transportation systems: An action guide for city leaders. . National League of Cities.

Murray, K. B., \& Schlacter, J. L. (1990). The impact of services versus goods on consumers' assessment of perceived risk and variability. 
Journal of the Academy of Marketing Science, 18(1), 51-65. doi:10.1007/BF02729762

O'Neill, E., Moore, D., Kelleher, L., \& Brereton, F. (2019). Barriers to electric vehicle uptake in Ireland: Perspectives of car-dealers and policy-makers. Case Studies on Transport Policy, 7(1), 118-127.

Oliver, J. D., \& Rosen, D. E. (2010). Applying the environmental propensity framework: A segmented approach to hybrid electric vehicle marketing strategies. Journal of Marketing Theory and Practice, 18(4), 377-393.

Ozaki, R., \& Sevastyanova, K. (2011). Going hybrid: An analysis of consumer purchase motivations. Energy Policy, 39(5), 2217-2227.

Patterson, P. G., \& Spreng, R. A. (1997). Modelling the relationship between perceived value, satisfaction and repurchase intentions in a business-to-business, services context: an empirical examination. International Journal of service Industry management, 8(5), 414434.

Prud'homme, R., \& Koning, M. (2012). Transport Policy, 23(null), 60.

Qureshi, I. A., \& Lu, H. (2007). Urban transport and sustainable transport strategies: A case study of Karachi, Pakistan. Tsinghua Science and Technology, 12(3), 309-317.

Rathore, A. K., Ilavarasan, P. V., \& Dwivedi, Y. K. (2016). Social media content and product co-creation: an emerging paradigm. Journal of Enterprise Information Management.

Roberts, J. A., \& Bacon, D. R. (1997). Exploring the subtle relationships between environmental concern and ecologically conscious consumer behavior. Journal of business research, 40(1), 79-89.

Rogers, E. M. (2003). Diffusion of innovations (Vol. null).

Sabrina Habich Sobiegallaa, G., NiklasAnzinger, . (December 2018). Electric vehicle purchase intentions of Chinese, Russian and Brazilian citizens: An international comparative study. Journal of Cleaner Production Volume 205, 20 December 2018, Pages 188200.

Salmond, J., Sabel, C. E., \& Vardoulakis, S. (2018). Towards the integrated study of urban climate, air pollution, and public health. In: Multidisciplinary Digital Publishing Institute.

Salmond, J. A., Tadaki, M., Vardoulakis, S., Arbuthnott, K., Coutts, A., Demuzere, M., . . . Macintyre, H. (2016). Health and climate related ecosystem services provided by street trees in the urban environment. Environmental Health, 15(1), 95-111.

Sang, Y.-N., \& Bekhet, H. A. (2015). Modelling electric vehicle usage intentions: an empirical study in Malaysia. Journal of Cleaner Production, 92, 75-83. 
Santos, G., Behrendt, H., \& Teytelboym, A. (2010). Part II: Policy instruments for sustainable road transport. Research in transportation economics, 28(1), 46-91.

Schuitema, G., Anable, J., Skippon, S., Kinnear, N., . (2013). The role of instrumental, hedonic and symbolic attributes in the intention to adopt electric vehicles. Transp. Res. A Policy Pract. 48, 3949.http://dx.doi.org/10.1016/j.tra.2012.10.004.

Shareef, M. A., Mukerji, B., Dwivedi, Y. K., Rana, N. P., \& Islam, R. (2019). Social media marketing: Comparative effect of advertisement sources. Journal of Retailing and Consumer Services, 46, 58-69.

Shariff, N. M. (2012). Private vehicle ownership and transportation planning in Malaysia. Paper presented at the International Conference on Traffic and Transportation Engineering.

Sheth, J. N., Newman, B. I., \& Gross, B. L. (1991). Why we buy what we buy: A theory of consumption values. Journal of business research, 22(2), 159-170.

Star, T. (2019). Transport a big factor in global warming. Retrieved from https://www.thestar.com.my/opinion/letters/2019/11/27/transport-abig-factor-in-global-warming

Struben, J., \& Sterman, J. D. (2008). Transition challenges for alternative fuel vehicle and transportation systems. Environment and Planning B: Planning and Design, 35(6), 1070-1097.

T.L. Childers, C. L. C., J. Peck, S. Carson, . (2001). Hedonic and utilitarian motivations for online retail shopping behavior,. Journal of Retailing 7 (4), , pp. 511-535.

Tseng, H., Wu, J., \& Liu, X. (2013). Energy Policy, 61(null), 441.

Turcksin, L., Macharis, C., Lebeau, K., Boureima, F., Van Mierlo, J., Bram, S., . . Gorissen, L. (2011). A multi-actor multi-criteria framework to assess the stakeholder support for different biofuel options: The case of Belgium. Energy Policy, 39(1), 200-214.

UN. (2020). Sustainable development goals - decade of action. Retrieved from Available:.

https://www.un.org/sustainabledevelopment/decade-of-action/.

UNFCCC. (2019). A Long Way from Carbon-Neutral World by 2050, Big Emitters Must Boost National Commitments. SG/SM/19907ENV/DEV/2032 11 DECEMBER 2019. Retrieved from https://www.un.org/press/en/2019/sgsm19907.doc.htm

Usher, K., Woods, C., Casella, E., Glass, N., Wilson, R., Mayner, L., . . . Mather, C. (2014). Australian health professions student use of social media. Collegian, 21(2), 95-101. 
Vardoulakis, S., \& Kinney, P. (2019). Grand challenges in sustainable cities and health. Frontiers in Sustainable Cities, 1, 7.

Venkatesh, V. (2000). Determinants of perceived ease of use: Integrating control, intrinsic motivation, and emotion into the technology acceptance model. Information systems research, 11(4), 342-365.

Venkatesh, V., Morris, M. G., Davis, G. B., \& Davis, F. D. (2003). User acceptance of information technology: Toward a unified view. MIS quarterly, 425-478.

Venkatesh, V., Thong, J. Y., \& Xu, X. (2012). Consumer acceptance and use of information technology: extending the unified theory of acceptance and use of technology. MIS quarterly, 157-178.

Wu, X., Dong, J., \& Lin, Z. (2014). Energy Policy, 68(null), 206.

Yadav, R., \& Pathak, G. S. (2016). Young consumers' intention towards buying green products in a developing nation: Extending the theory of planned behavior. Journal of Cleaner Production, 135, 732-739.

Zeng, B., \& Gerritsen, R. (2014). What do we know about social media in tourism? A review. Tourism management perspectives, 10, 27-36.

Zhang, Y., Yu, Y., \& Zou, B. (2011). Analyzing public awareness and acceptance of alternative fuel vehicles in China: The case of EV. Energy Policy, 39(11), 7015-7024.

Zhu, Y.-Q., \& Chen, H.-G. (2015). Social media and human need satisfaction: Implications for social media marketing. Business horizons, 58(3), 335-345.

Zimmer, M. R., Stafford, T. F., \& Stafford, M. R. (1994). Green issues: dimensions of environmental concern. Journal of business research, 30(1), 63-74. 